\title{
Pediatri Doktor ve Hemşirelerinde Öfke, Problem Çözme ve Tükenmişlik (Sivas İl Örneği)
}

\author{
Canan KELEŞ ${ }^{1}$, Ferdă̆ YILDIRIM²*
}

${ }^{1}$ Sivas Cumhuriyet Üniversitesi Uygulama ve Araştırma Hastanesi, Çocuk Yoğun Bakım Ünitesi, Sivas, Türkiye ${ }^{2}$ Sivas Cumhuriyet Üniversitesi, Sağlık Bilimleri Fakültesi, Hemşirelik Bölümü, Çocuk Sağlığı ve Hastalıkları Hemşireliği Anabilim Dalı, Sivas, Türkiye

$\begin{array}{ccc}\text { Geliş Tarihi } & \text { Kabul Tarihi } & \text { Yayın Tarihi } \\ 11.10 .2021 & 20.12 .2021 & 31.12 .2021\end{array}$

Özet: $\mathrm{Bu}$ araştırma pediatri doktor ve hemşirelerinin öfke, problem çözme ve tükenmişlik düzeylerini belirlemek amacıyla kesitsel-tanımlayıcı modelde tasarlanmıștır. 92 hemşire ve 51 doktor ile yapılan araştırmanın verileri 'Kişisel Bilgi Formu', 'Öfke ve Öfkeyi İfade Etme Tarzı Ölçeği, 'Problem Çözme Envanteri' ve 'Maslach Tükenmişlik Ölçeği' kullanılarak toplanmış, SSPS 22,0 programında analiz edilmiştir. Veriler Mann-Whitney U, Kruskall-Wallis ve Pearson korelasyon testleri ile değerlendirilmiştir. Örneklem grubunu oluşturan pediatri hemşirelerinin öfke kontrol düzeylerinin yüksek $(20,86 \pm 6,70)$, problem çözme becerilerinin zayıf (hemşire $=2,34 \pm 0,68)$ olduğu, pediatri doktorlarının öfke kontrolünün zayıf $(21,63 \pm 6,52)$, problem çözme becerilerinin yüksek $(2,46 \pm 0,47)$ olduğu ve her iki meslek grubunun da tükenmişlik yaşadıkları (doktor=28,61 $\pm 12,06$, hemşire=26,90 $\pm 11,90$ ) belirlenmiştir. Araştırmada sürekli öfke ile tükenmişlik arasında pozitif yönlü orta dereceli, problem çözme ile tükenmişlik arasında negatif yönde zayıf ilişki belirlenmiştir. Belirlenen sonuçlar doğrultusunda; hemşirelik eğitiminde olduğu kadar, mezuniyet sonrasında da kurumlarda öfke ve problem çözme yeterliliğine yönelik programların geliştirilmesi önerilmektedir.

Anahtar kelimeler: Doktor, Hemşire, Öfke, Problem, Tükenmişlik

\section{Anger, Problem Solving and Burnout in Pediatrics Doctors and Nurses (Sivas Province Example)}

\begin{abstract}
This study was designed in a cross-sectional-descriptive model to determine the anger, problem solving and burnout levels of pediatric doctors and nurses. The data of the research conducted with 92 nurses and 51 doctors were collected using the 'Personal Information Form', the 'Anger and Anger Expression Style Scale', the 'Problem Solving Inventory' and the 'Maslach Burnout Scale' and were analyzed in the SSPS 22.0 program. Data were evaluated with Mann-Whitney U, Kruskall-Wallis and Pearson correlation tests. Pediatric nurses who constitute the sample group have high anger control levels (20.86 \pm 6.70$)$, poor problem-solving skills (nurse $=2.34 \pm 0.68$ ), and pediatric doctors have weak anger control levels (21.63 \pm 6.52 ). It was determined that problem solving skills were high $(2.46 \pm 0.47)$ and both occupational groups experienced burnout (doctor=28.61 \pm 12.06 , nurse $=26.90 \pm 11.90$ ). In the study, a moderate positive correlation was found between trait anger and burnout, and a weak negative correlation between problem solving and burnout. In line with the determined results; It is recommended to develop programs for anger and problem solving competence in institutions after graduation as well as in nursing education.
\end{abstract}

Keywords: Nursing; parenteral drug administration; intramuscular injection 


\section{GíRiş}

Yoğun iş yükü, ağır hasta bakımı, hasta ve yakınlarına duygusal destek vermek zorunda kalma gibi nedenler sağlık çalışanlarında öfke, problemleri çözmede zorlanma gibi etkilere yol açmaktadır. Ayrıca sağlık hizmetindeki yetersizlikler, rol belirsizliği, dikey ve yatay ilişkiler ve iletişimlerden kaynaklı sorunlar hasta yoğunluğu, hizmet ve personel dağılımındaki dengesizlikler ve sosyal destek yetersizliği uzun vadede tükenmeye neden olmaktadır (Thomas, 2004; Arcak ve Kasımoğlu, 2006; Bayrı, 2007; Song ve ark., 2009; Günüşen ve Üstün, 2010; Marakoğlu ve ark., 2013; Karakurt ve Ekinci, 2015; Kırılmaz ve ark., 2016; Lafçı ve ark., 2016).

Pediatri doktor ve hemşireleri, çocuk ve aileyi bakımın merkezine alan, yeni doğan döneminden başlayarak, ergenlik döneminin sonuna kadar çocuğun tüm gelişimsel dönemlerinin özeliklerini kapsayacak biçimde sağlık bakımı vermekten sorumlu olan (Çavuşoğlu, 2001; Törüner ve Büyükgönen, 2011; Terrive Carman, 2013; Conk ve ark., 2018) ve bu nedenle öfke ve tükenmişlik için büyük bir risk taşıyan sağlık profesyonelleridir (Ertem, 2008; Günüşen ve Üstün, 2010).

İnsanlarla yoğun ve süreğen ilișkide olan pediatri doktor ve hemşirelerinin iş ortamında yoğun öfke yaşamaları ve problem çözmede başarısız olmaları sonucunda tükenmişlik sendromu yaşama olasılığı artabilmektedir (Marakoğlu ve ark., 2013). Maslach ve Jackson (1981) tükenmişliği, "Fiziksel yoksunluk, çaresizlik duyguları, olumsuz benlik kavramı ve iş, yaşam ve benzeri durumlara yönelik olumsuz tutumları içeren bir psikolojik sendrom" olarak tanımlamaktadır. Pediatri doktorları ve hemşireleri tükenmişlik sendromunun neden olduğu duygusal yıpranma ve stresle baş etmekte zorlanır. Yoğun stres, fiziksel ve duygusal yıpranmanın da etkisinden kaynaklanan öfke ve tükenmişlik duyguları bakımın kalitesini olumsuz etkilerken, diğer yandan verilen bakımın etkinliğini artırmanın yollarından biri hemşire ve doktorların problem çözme becerisidir (Yüzer ve ark., 2008). Öfke kontrol edilebildiğinde hemșire ve doktorlara fayda ve farkındalı sağlayan, öğrenme içgüdüsünü ve problem çözme becerisini geliştirilebilen, mesleki tükenmişlik yaşamasını önleyebilen duygu olarak ifade edilmektedir (Erkek ve ark., 2006; Batıgün ve Oktay, 2014). Hemșire ve doktorların güvenli, kaliteli bakım ve tedavi verebilmelerini belirleyen en önemli özelliklerinden biri problem çözme becerileridir (Mc Ewen ve Brown, 2002; Dinçer, 2008). Problem çözme becerisi bir sorun için olası etkili çözümlere ulaşabilme ve çeşitli seçenekler arasından en etkili çözümü seçme ve uygulama olasılığını artırmaktadır. (D'Zurilla, Nezu ve Maydeu-Olivares, 2004). Problem çözme becerisi yüksek olan pediatri doktor ve hemşirelerinin, sağlıklı çözüm stratejileri üretebildiği (Tezel ve ark., 2009), kişilerarası ilişkilerde daha başarılı oldukları (Chan, 1998), bakım verdikleri hastaların ise sorunları ile daha iyi baş ettikleri, hastalarda mortalite ve morbidite oranlarının da düşük olduğu okunmuştur (Nezu ve Nezu, 2001; Hoyt, 2007) . $\mathrm{Bu}$ araștırmada, pediatri hekim ve hemşirelerinin öfke ifade tarzları, problem çözme becerileri ve mesleki tükenmişlik düzeyleri belirlenmiștir. Sağlık çalışanlarının unvanı, eğitim durumu, cinsiyeti, hizmet süresi ve çalıştıkları birime gibi değişkenlere göre farklılık gösterip göstermediği ve aralarında anlamlı bir ilişki olup olmadığı incelenmiştir.

\section{Araştırma soruları}

$\mathrm{Bu}$ araştırmada aşağıdaki sorulara yanıt aranmıștır:

1. Pediatri doktor ve hemşirelerinin öfke düzeyleri nedir?

2. Pediatri doktor ve hemşirelerinin problem çözme düzeyleri nedir?

3. Pediatri doktor ve hemşirelerinin tükenmişlik düzeyleri nedir?

4. Pediatri doktor ve hemşirelerinin öfke, problem çözme ve tükenmişlik düzeylerinin sosyodemografik özelliklerle ilişkisi düzeyi nedir? 


\section{GEREÇ ve YÖNTEM}

\section{Araştırmanın yeri ve zamanı}

Tanımlayıcı tipteki bu araştırma Kasım 2018Nisan 2019 tarihleri arasında Sivas kent merkezinde bulunan bir üniversite, bir devlet ve bir özel hastanenin pediatri servislerinde yapılmıștır.

\section{Araştırmanın evreni ve örneklemi}

Araştırmanın evrenini kent merkezinde bulunan 3 hastanedeki 60 doktor ve 157 hemşire olmak üzere toplam 217 kişi, örneklemini araştırmaya katılmayı kabul eden ve anket formlarını tam dolduran 51 doktor, 92 hemşire ile toplam 143 kiși olușturmuștur. Veriler Kișisel Bilgi Formu, Sürekli Öfke ve Öfke Tarzı Ölçeği, Problem Çözme Envanteri ve Maslach Tükenmişlik Ölçeği kullanılarak toplanmıştır.

Kişisel bilgi formu, katılımcların bireysel ve mesleki özelliklerini içeren toplam 12 sorudan oluşan ve literatürden yararlanılarak oluşturulmuş bir anket formudur.

Sürekli Öfke-Öfke Ífade Tarzı Ölçeği (Trait Anger and Anger Expression Scales), (TAAES) (SÖÖİTÖ) Spielberger ve arkadaşları tarafından 1983 yılında geliștirilen, 34 maddelik 4'lü likert tipi ölçeğin Türkçe'ye uyarlanması Özer (1994) tarafından yapılmıştır. Kişinin genelde kendini nasıl hissettiğini, ne derece öfke yaşadığını ifade eden ölçekten alınabilecek en düşük puan 10, en yüksek puan 40'tır. Orjinal ölçeğin Cronbach Alfa değeri 77 ile 88 arasındadır (Keskin ve Ark., 2011). Bu çalışmada Cronbach Alfa değerleri "sürekli öfke" (SB) için \%88.2, "öfke kontrolü" (ÖK) boyutu için \%87.2, "öfke dişa vurumu" (ÖDV) boyutu için \%81.2 ve "öfke içe vurumu" (ÖIV) boyutu için \%72 9 olarak bulunmuştur.

Problem Çözme Ölçeği; P.P. Heppner ve C.H. Peterson tarafından 1982 yılında, kişinin kendi sorun çözme yaklaşımları hakkında ne algıladığını belirlemek amacı ile geliștirilen ölçeğin Türkçeye uyarlaması Taylan ve Şahin (1990), Şahin ve Heppner tarafından (1993) yapılmıştır. Likert tipinde, olumlu ve olumsuz 35 maddeden oluşan ve 32 madde üzerinden hesaplan bir ölçektir. Düşük puan sorun çözmede etkililiği ifade ederken, yüksek puan sorunlar karşısında kendini yetersiz olarak algıladığını göstermektedir. Ölçek, "Problem Çözme Yeteneğine Güven" (PÇYG), "Yaklaşmakaçınma" (YK) ve "Kişisel kontrol" (KK) maddelerinden oluşmaktadır (Savaşır ve Şahin 1997). Bu çalışmada Cronbach Alfa değerlerleri; Problem Çözme Yeteneğine Güven \%83, 9, kişisel kontrol \%85.3, problem çözme \%77.2 olarak bulunmuştur.

Maslach Tükenmişlik Ölçeği, Maslach tarafından geliştirilen ve tükenmişlik sendromunun değerlendirilmesinde en yaygın kullanılan ölçektir. Türkiye için geçerlilik ve güvenirlilik çalışması 1992 yılında Ergin ve ark tarafından yapılmıştır. Üç alt boyutu olan, 22 maddelik Maslach Tükenmișlik Ölçeği'nde elde edilen puanların yorumlanması; "duygusal tükenme" (DT) için, 0-16 puan düşük, 17-26 arası normal, 27 ve üzeri yüksek, "duyarsızlaşma" (D) için 0-6 arası düşük, 7-12 arası normal, 13 ve üzeri yüksek ve "kişisel başarı" (KB) için 39 ve üzeri düşük, 32-38 arası normal, 0-31 arası yüksek şeklinde sınıflandırılmıştır. $\mathrm{Bu}$ çalışmada Cronbach Alfa değerlerleri duygusal tükenme için. $(\mathrm{p}<0,05)$. 88.8, duyarsızlaşma için 86.6, kişisel başarı için 88.0 ve tükenmişlik sendromu için 80.6 olarak bulunmuştur.

\section{Araştırmanın uygulanması}

Araştırma verileri, Kasım 2018-Nisan 2019 tarihleri arasında hemşire ve doktorların çalışma ortamlarında, yüz yüze görüşme yoluyla toplanmıştır. Hemşire ve doktorlara araştırma öncesi açıklama yapılmış, yazılı ve sözlü onamları alınarak veri toplama formlarını doldurmaları sağlanmıştır.

\section{Verilerin değerlendirilmesi}

Kasım 2018-Nisan 2019 tarihleri arasında SPSS (Statistical Packagefor Social Sciences) version 22 programı kullanılarak yapılan değerlendirmede tanımlayıcı istatistiksel ölçütlerin yanı sıra, Mann Whitney U ve Kruskal Wallis testleri kullanılmıștır. Araştırmada $p$ $<0,05$ anlamlı olarak kabul edilmiştir. 


\section{Araştırmanın sınırlılıkları}

Araştırma örneklemi Sivas ili çocuk kliniklerinde çalışan ve araştırmaya gönüllü olarak katılmayı kabul eden hemşire ve hekimlerle sınırlıdır.

\section{Araştırmanın etik yönü}

Uygulamaya geçmeden önce Sivas Cumhuriyet Üniversitesi Girişimsel Olmayan Etik Kurul'dan 10.09.2018 tarihli 326718 sayll, Numune Hastanesi'nden 93848782, Cumhuriyet Üniversitesi Uygulama ve Araştırma Hastanesi'nden 12135 ve Gültepe Hastanesi'nden 88354726 sayılı yazılı izinler alınmıștır.

\section{BULGULAR}

Örneklem grubunu oluşturan pediatri hemşirelerinin \%76.2'sinin 25 yaş altında, pediatri hekimlerinin \%38.3'inin 26-35 yaş aralığında oldukları, hemşirelerin \%75.4'ünün, hekimlerin \%24.6'sının kadın olduğu, hemşirelerin \%70.5, hekimlerin \%29.5'inin evli, hemşirelerin \%68.8'inin, hekimlerin \%31.2'sinin çocuk sahibi olduğu belirlenmiştir. Hemşirelerin \%98.2'si lisansüstü eğitim mezunudur.

Tablo 1'de hemşirelerin KK dişındaki PÇYG, YK ve Problem Çözme Toplam puan ortalamalarının yüksek ve istatistiksel olarak anlamlı olduğu $(\mathrm{p}<0,05) \quad$ görülmektedir. Hekimlerin Tükenmişlik alt boyut puan ortalamalarının tümü yüksek olup, Duyarsızlaşma ve Tükenmişlik Toplam ölçek puan ortalamaları arasındaki fark istatistiksel olarak $(\mathrm{p}<0,05)$ anlamlıdır.

Tablo 2'de hemşire ve hekimlerin Devlet, Üniversite ya da Özel hastanelerde çalışıyor olmaları ve meslekte ve pediatri servislerinde çalışma süreleri ile öfke ölçeği puan ortalamaları arasinda anlamlı bir fark ( $>>0.05)$ bulunmaz iken, hemşirelerin mesleği nasıl tercih ettiği ile ÖK ve ÖÖTP arasında ve çalıştığı kurumda kendini nasıl hissettiği ile IV arasında, hekimlerin mesleği nasıl tercih ettiği ile SÖ, DV ve ÖÖTP arasında ve çalıştığı kurumda kendini nasıl hissettiği ile SÖ, DV ve ÖÖTP arasında istatiksel olarak anlamlı bir ilişki bulunmuştur $(\mathrm{p}<0,05)$.

Tablo 3'de hemşirelerin yaşı ve eğitim düzeyi ile problem çözme KK alt boyut puan ortalamaları arasında istatistiksel olarak anlamlı bir fark olduğu $(p<0,05)$, Mann Whitney U testinde farkın 26-35 yaştan kaynaklandığı belirlenmiştir. Hekimlerin yaşı ile YK ve KK alt boyut puan ortalamaları arasında anlamlı bir fark olduğu $(\mathrm{p}<0,05)$, Mann Whitney $U$ testinde YK puanındaki farkın 25, KK puanındaki farkın 55 yaş üstünden kaynaklandığı belirlenmiştir.

Kadın doktorların PÇKG, erkek doktorların KK puan ortalamaları, bekar doktorların YK ve problem çözme toplam puan ortalamalarının yüksek ve istatistiksel olarak anlamlı olduğu $(p<0,05)$ belirlenmiştir. Çocuğu olan hekimlerin PÇYG, YK ve KK puan ortalamalarının çocuğu olmayan hekimlerden yüksek ve istatistiksel olarak önemli olduğu $(\mathrm{p}<0,05)$ belirlenmiştir.

Tablo 4'de Pediatri servisinde 6-10 yıldır çalışan hemşirelerin KK puan ortalamalarının, henüz bir yıldır ve 10 ila 20 yılın üzerinde çalışan hemşirelerin puan ortalamalarından yüksek ve istatistiksel olarak anlamlı olduğu $(p=0,034)$ $(\mathrm{p}<0,05), 1$ yıldır çalışan hekimlerin YK $(p=0,009)$ ve 11-20 yıldır çalışan hekimlerin KK puan ortalamalarının yüksek ve istatistiksel olarak anlamlı $(\mathrm{p}=0,037) \quad(\mathrm{p}<0,05) \quad$ olduğu görülmektedir.

Meslekte çalışma süresi 1-5 yıl arasında olan doktorların PÇKG puan ortalamaları $(\mathrm{p}=0,007)$, YK davranışları puan ortalamaları $(p=0,023)$ ve toplam problem çözme puan ortalamaları yüksek ve istatistiksel olarak anlamlıdır $(\mathrm{p}<0,05)$.

Pediatri hemşirelerinin çalıștığı kurumu ile YK $(p=0,006)$ arasinda istatistiksel olarak anlamlı bir farklılık hesaplanmış ( $p>0,05)$, farklılığın üniversite hastanesinde çalışan hemşirelerden kaynaklandığı $\quad(\mathrm{p}<0,05) \quad$ belirlenmiştir. Hekimlerin çalıştığı kurum ile YK $(p=0,020)$ ve toplam problem çözme puan ortalamaları arasında istatistiksel bir fark olduğu $(\mathrm{p}<0,05)$, her iki alt boyuttaki farkın özel hastanelerde çalışan hekimlerden kaynaklandığı belirlenmiştir.

Pediatri hemşirelerinin meslek seçimleri ile YK puan ortalamaları $(p=0,036)$ arasında anlaml farklılık hesaplanmıș $(\mathrm{p}<0,05)$ farklılığın meslek seçimini kendisi yapan hemşirelerden kaynaklandığı belirlenmiştir. 
Tablo 5'de Tükenmişlik DT ile hekimlerin yaşı $(p=0,048)$, cinsiyeti $(p=0,013)$ (fark kadın hekimlerden kaynaklanmaktadır) ve çocuğu olup olmaması $(p=0,009)$ arasındaki farkın istatistiksel olarak anlamlı olduğu $(p<0,05)$ belirlenmiştir.

Evli hemşire $(\mathrm{p}=0,039)$ ve doktorların KB puan ortalamaları $(\mathrm{p}=0,025)$ evli olmayanlara göre daha yüksek ve arasındaki fark da istatistiksel olarak anlamlıdır $(\mathrm{p}<0,05)$.

Çocuğu olmayan hemşirelerin DT ve D alt maddeleri ile $(p<0,05)$, çocuğu olmayan hekimlerin ölçek toplam puanı dışındaki tükenmişlik puan ortalamaları arasında istatistiksel anlamlı fark $(p<0,05)$ olduğu belirlenmiștir.

Hemşirelerin DT $(38.00 \pm 18,19)$ ve D $(17.00 \pm 9,64)$ puan ortalamalarının diğer eğitim düzeylerine göre daha yüksek ve istatistiksel olarak anlamlı olduğu $(\mathrm{p}<0,05)$ belirlenmiştir.

Tablo 6'da meslekte çalışma süresi ile hekimlerin DT puan ortalamaları arasında $(\mathrm{p}=0,020)$ ve çalıştığ duyarsızlaşmaları arasında $(p=0,020)$ (anlamlı bir istatistiksel ilişki olduğu belirlenmiştir $\mathrm{p}<0,05)$. Meslek seçimini aile isteği ile belirleyen hemşirelerin $D(p=0,007)$ ve tükenmişlik toplam ölçek puanı $(p=0,016)$, doktorların DK $(p=0,009)$ ve tükenmişlik toplam ölçek puanı $(p=0,007)$ olarak hesaplanmış ve istatistiksel olarak da anlamlı bulunmuştur.

\section{TARTIŞMA}

\section{Hekim ve hemşirelerin kişisel ve mesleki özellikleri ile öfke tartışması}

$\mathrm{Bu}$ çalışmadaki pediatri doktor ve hemşirelerinin öfkelerinin yüksek (ort=78,71), sürekli öfke düzeylerinin ortalamanın üzerinde (ort=21,13) olduğu, bununla birlikte öfkelerini kontrol edebildikleri (ort $=24,05$ ) ve doğrudan dışa vurmadıkları belirlenmiştir (Tablo 1). Cinsiyete göre yapılan analizde kadın doktorların ve erkek hemşirelerin orta düzeyde öfkeleri olduğu (Tablo 2), Kaya ve Solmaz (2000) ve Kocaman'ın (2017) çalışmaları ile benzerlik, Doğan ve ark., (1999), Engin (2004) ve Bayrı ve Kelleci (2009)'nin hemşirelerin sürekli öfkelerini düşük bulduğu çalışmalar ile farklılık gösterdiği belirlenmiştir.

Tablo 1. Öfke ve Öfke İfade Tarzı, Problem Çözme ve Maclach Tükenmişlik Ölçek ve Alt Boyutları Analizi

\begin{tabular}{|c|c|c|c|}
\hline & Hemşire $\bar{x} \pm s s$ & Doktor $\overline{\mathbf{x}} \pm \mathrm{sS}$ & $\mathbf{p}$ \\
\hline \multicolumn{4}{|l|}{ Öfke ve öfke ifade tarzı } \\
\hline Sürekli Öfke & $20,86 \pm 6,70$ & $21,63 \pm 6,52$ & 0,397 \\
\hline İçe Vurum & $17,90 \pm 4,49$ & $17,98 \pm 4,88$ & 0,944 \\
\hline Dișa Vurum & $15,76 \pm 5,13$ & $15,31 \pm 3,88$ & 0,985 \\
\hline Öfke Kontrolü & $23,48 \pm 5,72$ & $25,08 \pm 5,13$ & 0,132 \\
\hline Öfke Ölçeği Toplam Puan & $78,00 \pm 12,38$ & $80,00 \pm 12,65$ & 0,317 \\
\hline \multicolumn{4}{|l|}{ Problem çözme } \\
\hline Problem Çözme Yeteneğine Güven & $2,34 \pm 0,68$ & $2,03 \pm 0,72$ & 0,002 \\
\hline Yaklaşma-Kaçınma & $2,56 \pm 0,62$ & $2,17 \pm 0,69$ & $<0,001$ \\
\hline Kişisel Kontrol & $3,95 \pm 1,18$ & $4,24 \pm 1,18$ & 0,263 \\
\hline Problem Çözme Ölçeği & $2,72 \pm 0,44$ & $2,46 \pm 0,47$ & 0,001 \\
\hline \multicolumn{4}{|l|}{ Tükenmişlik } \\
\hline Duygusal Tükenme & $26,90 \pm 11,90$ & $28,61 \pm 12,06$ & 422 \\
\hline Duyarsızlașma & $9,21 \pm 6,60$ & $11,33 \pm 6,64$ & 0,028 \\
\hline Kişisel Başarı & $32,67 \pm 10,67$ & $35,22 \pm 9,12$ & 0,205 \\
\hline Tükenmişlik Ölçeği Toplam Puan & $68,78 \pm 18,05$ & $75,16 \pm 14,55$ & 0,038 \\
\hline
\end{tabular}

Test=Mann-Whitney $U$

Bizim çalışmamızda 25 yaş altındaki hemşirelerin sürekli öfkeli, 46-55 yaş aralığındaki hemşirelerin öfkelerini kontrol edebildikleri bulunmuştur (Tablo 2). Bir çalışmada 18-24 yaşlarındaki hemşirelerin öfkelerini dışa yansitmaları yüksek (Yüksel, 2014) olup, bizim çalışmamızla paralellik gösterirken, bir çalışmada yaş ile sürekli öfke, öfkenin içe, dışa yansıtılması ve öfke kontrolü arasında anlamlı bir fark olmadı ğı (Engin, 2004) belirlenmiştir.

$\mathrm{Bu}$ çalışmanın sonuçlarına göre erkek hemşirelerde ve kadın doktorlarda sürekli öfke düzeyinin yüksek olduğu belirlenmiştir (Tablo 2). Bir çalışmada öfke kontrolünün yüksek, sürekli öfkenin orta düzeyde ve cinsiyet 
yönünden öfke düzeyleri ve ifade biçimlerinde anlamlı bir farklılık olmadığı belirlenmiştir (Baran, 2009; Yüksel, 2014). İlhan (2014) çalışmasında erkek hemşirelerin kadın hemşirelerden daha öfkeli olduğunu bulmuştur.

Tablo 2. Pediatri Hemșire ve Hekimlerinin Kișisel Özelliklerine Göre Problem Çözme Puan Ortalamaları

\begin{tabular}{|c|c|c|c|c|c|c|}
\hline & & SÖ. $\overline{\mathrm{x}} \pm \mathrm{sS}$ & $\overline{I V} \bar{x} \pm s s$ & DV. $\overline{\mathrm{x}} \pm \mathrm{sS}$ & ÖK. $\bar{x} \pm s S$ & ÖT $\overline{\mathrm{x}} \pm \mathrm{sS}$ \\
\hline \multicolumn{7}{|l|}{ Cinsiyet } \\
\hline & Kadın & $20,69 \pm 6,57$ & $18,01 \pm 4,58$ & $15,77 \pm 5,21$ & $23,62 \pm 5,76$ & $78,08 \pm 12,45$ \\
\hline \multirow[t]{2}{*}{ Hemşire* } & Erkek & $23,33 \pm 8,69$ & $16,33 \pm 2,80$ & $15,67 \pm 4,23$ & $21,5 \pm 5,24$ & $76,83 \pm 12,42$ \\
\hline & Kadın & $\begin{array}{l}p=0,43 \\
23,50 \pm 6,03\end{array}$ & $\begin{array}{l}p=0,360 \\
19,18 \pm 4,89\end{array}$ & $\begin{array}{l}p=0,956 \\
16,11 \pm 4,09\end{array}$ & $\begin{array}{l}p=0,2 / 4 \\
23,93 \pm 5,16\end{array}$ & $\begin{array}{l}p=0,818 \\
82,71 \pm 13,33\end{array}$ \\
\hline Hekim* & Erkek & $\begin{array}{l}19,35 \pm 6,48 \\
p=\mathbf{0 , 0 1 8}\end{array}$ & $\begin{array}{l}16,52 \pm 4,56 \\
p=0,058\end{array}$ & $\begin{array}{l}14,35 \pm 3,46 \\
p=0,148\end{array}$ & $\begin{array}{l}26,48 \pm 4,85 \\
p=0,070\end{array}$ & $\begin{array}{l}76,7 \pm 11,16 \\
p=0,073\end{array}$ \\
\hline \multicolumn{7}{|c|}{ Medeni Durum } \\
\hline \multirow[b]{2}{*}{ Hemşire** } & Kadın & $20,15 \pm 6,03$ & $17,87 \pm 4,95$ & $15,61 \pm 5,07$ & $23,24 \pm 6,03$ & $76,87 \pm 12,12$ \\
\hline & Erkek & $\begin{array}{l}22,33 \pm 7,81 \\
p=0,168\end{array}$ & $\begin{array}{l}17,97 \pm 3,44 \\
p=0,841\end{array}$ & $\begin{array}{l}16,07 \pm 5,34 \\
p=0,792\end{array}$ & $\begin{array}{l}23,97 \pm 5,1 \\
p=0,802\end{array}$ & $\begin{array}{l}80,33 \pm 12,81 \\
p=0,235\end{array}$ \\
\hline \multirow{3}{*}{ Hekim** } & Evli & $22,23 \pm 6,97$ & $18,5 \pm 5,53$ & $15,69 \pm 4,15$ & $26,92 \pm 4,97$ & $83,35 \pm 11,88$ \\
\hline & Bekar & $20,74 \pm 6,22$ & $17,26 \pm 4,22$ & $15.00 \pm 3,67$ & $23,26 \pm 4,81$ & $76,26 \pm 13,14$ \\
\hline & Dul & $\begin{array}{l}24.00 \pm 4,24 \\
p=0,561\end{array}$ & $\begin{array}{l}19,50 \pm 3,54 \\
p=0,562\end{array}$ & $\begin{array}{l}14.00 \pm 4,24 \\
p=0,693\end{array}$ & $\begin{array}{l}22.00 \pm 2,83 \\
p=\mathbf{0 , 0 2 3}\end{array}$ & $\begin{array}{l}79,50 \pm 7,78 \\
p=0,157\end{array}$ \\
\hline \multicolumn{7}{|c|}{ Çocuğu Olup Olmaması } \\
\hline \multirow{3}{*}{ Hemşire } & Var & $19,98 \pm 6,48$ & $17,32 \pm 4,64$ & $15,64 \pm 5,39$ & $22,89 \pm 6,05$ & $75,83 \pm 11,66$ \\
\hline & Yok & $\begin{array}{l}22,05 \pm 6,89 \\
p=0,082\end{array}$ & $\begin{array}{l}18,69 \pm 4,22 \\
p=0,175\end{array}$ & $\begin{array}{l}15,92 \pm 4,83 \\
p=0,609\end{array}$ & $\begin{array}{l}24,28 \pm 5,22 \\
p=0,303\end{array}$ & $\begin{array}{l}80,95 \pm 12,87 \\
p=0,069\end{array}$ \\
\hline & Var & $21,21 \pm 6,56$ & $17,96 \pm 5,65$ & $14,92 \pm 3,66$ & $27,58 \pm 4,57$ & $81,67 \pm 11,56$ \\
\hline Hekim & Yok & $\begin{array}{l}22.00 \pm 6,58 \\
p=0,596\end{array}$ & $\begin{array}{l}18.00 \pm 4,21 \\
p=0,880\end{array}$ & $\begin{array}{l}15,67 \pm 4,10 \\
p=0,656\end{array}$ & $\begin{array}{l}22,85 \pm 4,61 \\
p=\mathbf{0 , 0 0 1}\end{array}$ & $\begin{array}{l}78,52 \pm 13,58 \\
p=0,473\end{array}$ \\
\hline \multicolumn{7}{|c|}{ Meslek Seçimi } \\
\hline \multirow{4}{*}{ Hemşire** } & Kendisi & $19,65 \pm 6,28$ & $17,39 \pm 4,72$ & $14,8 \pm 4,45$ & $23,08 \pm 4,86$ & $74,92 \pm 13,13$ \\
\hline & Ailesi & $22,22 \pm 7,11$ & $19,52 \pm 4,16$ & $16,04 \pm 5.00$ & $25,37 \pm 6,54$ & $83,15 \pm 10,2$ \\
\hline & Tesadüf & $22,25 \pm 6,95$ & $16,75 \pm 3,77$ & $18,25 \pm 6,58$ & $21,5 \pm 6,14$ & $78,75 \pm 10,91$ \\
\hline & & $\mathrm{p}=0,131$ & $\mathrm{p}=0,051$ & $\mathrm{p}=0,078$ & $p=0,025$ & 0,006 \\
\hline \multirow{3}{*}{ Hekim** } & Kendisi & $20,77 \pm 6,34$ & $17,45 \pm 4,8$ & $14,8 \pm 3,84$ & $25,5 \pm 5,29$ & $78,52 \pm 12,44$ \\
\hline & Ailesi & $27.00 \pm 5,2$ & $21,29 \pm 4,39$ & $18,57 \pm 2,3$ & $22,43 \pm 3,05$ & $89,29 \pm 10,36$ \\
\hline & & $p=0,013$ & $\mathrm{p}=0,062$ & $p=0,009$ & $\mathrm{p}=0,102$ & $p=0,037$ \\
\hline \multicolumn{7}{|c|}{ Çalıştığı Kurumda Kendini İyi Hissetme } \\
\hline & Evet & $20,26 \pm 6,65$ & $19,48 \pm 4,14$ & $15,78 \pm 5,11$ & $22,52 \pm 6,65$ & $78,04 \pm 12,72$ \\
\hline \multirow[t]{2}{*}{ Hemşire } & Hayır & $21,06 \pm 6,75$ & $17,38 \pm 4,51$ & $15,75 \pm 5,18$ & $23,8 \pm, 39$ & $77,99 \pm 12,36$ \\
\hline & Evet & $\begin{array}{l}p=0,946 \\
18,95 \pm 5,79\end{array}$ & $16,26 \pm 4,58$ & $14.00 \pm 3,11$ & $\begin{array}{l}\mathrm{p}=0,470 \\
24,42 \pm 5,86\end{array}$ & $\begin{array}{l}\mathrm{p}=0,658 \\
73,63 \pm 11,45\end{array}$ \\
\hline Doktor & Hayır & $\begin{array}{l}23,22 \pm 6,48 \\
\mathbf{p}=\mathbf{0 , 0 1 3}\end{array}$ & $\begin{array}{l}19.00 \pm 4,84 \\
p=0,062\end{array}$ & $\begin{array}{l}16,09 \pm 4,12 \\
\mathbf{p}=\mathbf{0 , 0 0 9}\end{array}$ & $\begin{array}{l}25,47 \pm 4,7 \\
p=0,102\end{array}$ & $\begin{array}{l}83,78 \pm 11,93 \\
\mathbf{p}=\mathbf{0 , 0 3 7}\end{array}$ \\
\hline
\end{tabular}

* Mann Whitney U testi, ${ }^{* *}$ Kruskal Wallis H testi

Benzer şekilde iki çalışma erkeklerde öfkenin daha yüksek olduğunu göstermektedir (Keskin ve ark., 2011; Cebeci, 2018). Durmuş ve ark. (2000) ve Ylldırım ve ark., (2002)'nın çalışmalarında hemşirelerin sürekli öfke puan ortalamalarının yüksek olduğunu ve kadın doktorların daha fazla öfke yaşadıklarını belirtmişlerdir. Çalışmamızda bekar hemşirelerin $(22,33 \pm 7,81)$ ve evli doktorların $(22,23 \pm 6,97)$ sürekli öfkeli oldukları belirlenmiştir (Tablo 2). Hemşirelerin öfke kontrolleri medeni durumlarına göre farklılık göstermemekte iken evli doktorların $(26,92 \pm 4,97)$ öfkelerinin daha yüksek olduğu saptanmıştır. Engin (2004) ve Cebeci (2018) evli hemşirelerin, Portakal (2018) bekar hemşirelerin öfke kontrol düzeylerini yüksek bulmuştur. Yılmaz (2009)'ın çalışmasında çocuğu olan hemşirelerin öfkelerini kontrol edebildikleri, çocuk sahibi olmayan pediatri hemşirelerinin sürekli öfkeli oldukları ve öfkelerini dışa yönelttikleri belirlenmiştir.

Eğitim düzeyinin öfkeyi etkilediği, ön lisans mezunu hemşirelerin sürekli öfkeli olduğu $(31,33 \pm 11,72)$ ve öfkelerini dışa vurdukları (22.33 \pm 6.03 ) belirlenmiştir (Tablo 2). Bir çalışmada eğitim düzeyi azaldıkça hemşirelerin 
sürekli öfke ve öfkelerini dışa vurumlarının yüksek (Engin, 2004), diğer iki çalışmada lisans mezunu hemşirelerin sağlık meslek lisesi mezunu hemşirelere göre daha kontrollü oldukları belirlenmiştir (Yıldırım, 2005; İlhan, 2014). Balkaya ve Şahin'in (2003) çalışmalarında lise ve üniversite mezunlarının öfkeye yol açan durumlardan daha fazla etkilendiği daha fazla öfke yaşadığı ve öfkeyi dışa vurumda lise mezunlarından daha rahat olduğu belirtilmiştir.
Bu çalışmada, Pediatri servisinde 20 yıl üzerinde çalışan hemşirelerin daha az, doktorların daha öfkeli oldukları (Tablo 2) belirlenmiştir. Akkoç (2011) çalışmasındaki sağlık çalışanlarının öfkesi ile çalışma yılı arasında anlamlı bir farklılık belirtmemiştir. Meslek seçimini aile isteği ile belirleyen hemşirelerin ve doktorların öfkeli oldukları bulunmuştur.

Tablo 3. Pediatri Hemşire ve Hekimlerinin Kişisel Özelliklerine Göre Problem Çözme Puan Ortalamaları

\begin{tabular}{|c|c|c|c|c|c|}
\hline & & PCYG $\bar{x} \pm S S$ & YKX̄ $\pm s S$ & KK $\bar{x} \pm s S$ & PÇTÖP $\bar{x} \pm s S$ \\
\hline \multicolumn{6}{|l|}{ Yaşı } \\
\hline & 25 ve Altı & $2,64 \pm 0,90$ & $2,82 \pm 0,72$ & $3,11 \pm 1,38$ & $2,84 \pm 0,54$ \\
\hline & $26-35$ & $2,31 \pm 0,6$ & $2,48 \pm 0,63$ & $4,15 \pm 1,09$ & $2,69 \pm 0,42$ \\
\hline \multirow[t]{5}{*}{ Hemşire** } & $36-45$ & $2,18 \pm 0,58$ & $2,52 \pm 0,53$ & $4,13 \pm 1,06$ & $2,67 \pm 0,39$ \\
\hline & $46-55$ & $2,52 \pm 0,73$ & $2,56 \pm 0,68$ & $4,02 \pm 1,11$ & $2,73 \pm 0,51$ \\
\hline & & $\mathrm{p}=0,208$ & $\mathrm{p}=460$ & $p=0,034$ & $\mathrm{p}=0,712$ \\
\hline & 25 ve Altı & $2,51 \pm 0,69$ & $2,85 \pm 0,52$ & $3,60 \pm 1,57$ & $2,83 \pm 0,36$ \\
\hline & $26-35$ & $2,17 \pm 0,79$ & $2,33 \pm 0,75$ & $3,90 \pm 1,23$ & $2,52 \pm 0,53$ \\
\hline \multirow{4}{*}{ Doktor** } & $36-45$ & $1,88 \pm 0,62$ & $1,96 \pm 0,55$ & $4,46 \pm 0,82$ & $2,38 \pm 0,4$ \\
\hline & $46-55$ & $1,62 \pm 0,52$ & $1,68 \pm 0,28$ & $5,12 \pm 0,72$ & $2,21 \pm 0,22$ \\
\hline & 55 Üstü & $1,41 \pm 0,19$ & $1,59 \pm 0,22$ & $5,90 \pm 0,14$ & $2,21 \pm 0,3$ \\
\hline & & $\mathrm{p}=0,053$ & $p=0,009$ & $p=0,037$ & 0,130 \\
\hline \multicolumn{6}{|l|}{ Cinsiyeti } \\
\hline & Kadın & $2,34 \pm 0,68$ & $2,56 \pm 0,62$ & $3,95 \pm 1,21$ & $2,72 \pm 0,43$ \\
\hline \multirow[t]{2}{*}{ Hemşire* } & Erkek & $2,47 \pm 0,71$ & $2,47 \pm 0,7$ & $3,97 \pm 0,72$ & $2,70 \pm 0,59$ \\
\hline & & $\mathrm{p}=0,506$ & $\mathrm{p}=0,635$ & $\mathrm{p}=0,698$ & $\mathrm{p}=0,819$ \\
\hline \multirow{3}{*}{ Doktor* } & Kadın & $2,04 \pm 0,52$ & $2,21 \pm 0,61$ & $3,89 \pm 1,19$ & $2,44 \pm 0,34$ \\
\hline & Erkek & $2,01 \pm 0,92$ & $2,13 \pm 0,79$ & $4,67 \pm 1,05$ & $2,5 \pm 0,59$ \\
\hline & & $p=0,018$ & $\mathrm{p}=0,360$ & $p=0,026$ & $\mathrm{p}=0,232$ \\
\hline \multicolumn{6}{|c|}{ Eğitim durumu } \\
\hline \multirow{5}{*}{ Hemşire ${ }^{* *}$} & SML & $2,33 \pm 0,89$ & $2,61 \pm 0,86$ & $3,44 \pm 1,37$ & $2,69 \pm 0,60$ \\
\hline & ÖL & $2,88 \pm 0,5$ & $2,94 \pm 0,47$ & $2,67 \pm 0,23$ & $2,90 \pm 0,36$ \\
\hline & Lisans & $2,44 \pm 0,62$ & $2,58 \pm 0,55$ & $4,20 \pm 0,95$ & $2,77 \pm 0,39$ \\
\hline & YL & $1,94 \pm 0,45$ & $2,36 \pm 0,56$ & $3,96 \pm 1,48$ & $2,54 \pm 0,36$ \\
\hline & & & $\mathrm{p}=0,360$ & $p=0,026$ & $\mathrm{p}=0,232$ \\
\hline \multicolumn{6}{|c|}{ Medeni durumu } \\
\hline \multirow{3}{*}{ Hemşire** } & Evli & $2,29 \pm 0,66$ & $2,54 \pm 0,62$ & $4,02 \pm 1,22$ & $2,70 \pm 0,43$ \\
\hline & Bekar & $2,46 \pm 0,73$ & $2,59 \pm 0,64$ & $3,81 \pm 1,11$ & $2,74 \pm 0,46$ \\
\hline & & $\mathrm{p}=0,286$ & $\mathrm{p}=0,957$ & $\mathrm{p}=0,261$ & $\mathrm{p}=0,924$ \\
\hline \multirow{3}{*}{ Doktor** } & Evli & $1,81 \pm 0,57$ & $1,88 \pm 0,47$ & $4,62 \pm 1,1$ & $2,29 \pm 0,35$ \\
\hline & Bekar & $2,26 \pm 0,82$ & $2,47 \pm 0,75$ & $3,83 \pm 1,08$ & $2,64 \pm 0,53$ \\
\hline & & $\mathrm{p}=0,085$ & $\mathrm{p}=\mathbf{0 , 0 2 0}$ & $\mathrm{p}=0,133$ & $p=0,028$ \\
\hline \multicolumn{6}{|c|}{ Çocuğu olup olmadığı } \\
\hline \multirow{3}{*}{ Hemşire* } & Var & $2,33 \pm 0,63$ & $2,60 \pm 0,58$ & $4,07 \pm 1,18$ & $2,74 \pm 0,42$ \\
\hline & Yok & $2,36 \pm 0,75$ & $2,51 \pm 0,69$ & $3,79 \pm 1,18$ & $2,69 \pm 0,46$ \\
\hline & & $\mathrm{p}=0,937$ & $\mathrm{p}=0,397$ & $\mathrm{p}=0,191$ & $\mathrm{p}=0,404$ \\
\hline \multirow{3}{*}{ Doktor* } & Var & $2,04 \pm 0,52$ & $2,21 \pm 0,61$ & $3,89 \pm 1,19$ & $2,44 \pm 0,34$ \\
\hline & Yok & $2,01 \pm 0,92$ & $2,13 \pm 0,79$ & $4,67 \pm 1,05$ & $2,5 \pm 0,59$ \\
\hline & & $p=0,036$ & $p=0,025$ & $p=0,007$ & $\mathrm{p}=0,071$ \\
\hline
\end{tabular}

*Mann Whitney U testi, ${ }^{* *}$ Kruskal Wallis H testi.

Hekim ve hemşirelerin kişisel ve mesleki bulguları ile problem çözme tartışması

$\mathrm{Bu}$ çalışmada pediatri doktor ve hemşirelerinin problem çözme yeteneklerine güven duymadıkları, kaçınmacacı bir davranış sergiledikleri ve problem çözme algılarının düşük, kişisel kontrollerinin yüksek olduğu bulunmuştur (Tablo 1). Bahar (2006), Terzioglu (2006), ve Erkuş ve Bahçecik (2015)'in çalışmalarında hemşirelerin kendilerini orta düzeyde problem çözücü olarak algıladıklarını belirtmiştir. Hemşirelerin problem çözme 
becerilerini orta veya düşük düzeyde algılamalarının nedeni; bilimsel problem çözme sürecini zor, teorik, uygulamada zaman kaybı olarak görmeleri olduğu düşünülmektedir.

Pediatri hemşirelerinin problem çözme becerileri ve yaklaşımları yaş değişkeni ile farklılık göstermektedir (Tablo 3). 25 yaşın altındaki hemşirelerin kişisel kontrolleri $(3,11 \pm 1,38)$ diğer yaş gruplarına göre düşük bulunmuştur. Doktorların yaklaşma-kaçınma $(p=0,009)$ ve kişisel kontrol ortalamasında istatiksel olarak anlamlı hesaplanan farklılık ( $p=0,037$ ) 46-55 yaşında olanların puan ortalamalarının yüksek olmasından kaynaklanmaktadır $(\mathrm{p}<0,05)$. Abaan ve Altıntoprak'ın (2005), Çelik ve Yurdakul (2009) ve Erkuş'un (2011) çalışmalarında problem çözme ile yaş değişkeni arasında anlamlı bir ilişki saptanmamıştır. Kelleci ve Gölbaşı (2004)'nın çalışmasında 30 ve altı yaş grubunda olan hemşirelerin kendilerini, 31 yaş ve üzeri gruba göre problem çözme konusunda daha başarılı algıladıkları belirtilmiş. Erdem (1995) ve Ulupınar (1997) yaş ile problem çözme arasında ilişki olduğunu, hemşirelerin problem çözme becerilerinin yaşa göre değiștiğini $(p>0.05)$ ve yaş ilerledikçe problem çözme başarısının arttığ belirtmişlerdir.

Çalışmamızda erkek doktorların problem çözmede kişisel kontrollerinin kadın doktorlardan yüksek olduğu hesaplanmıştır ( $\mathrm{p}=0,042) \quad$ (Tablo 3). Polat (2013)'ın çalışmasında cinsiyet ile sorun çözme arasında istatistiksel yönden anlamlı bir farklılık bulunmamıştır $(p>0,05)$. Ancak erkeklerin, akılcı sorun çözme ve olumlu sorun yöneliminin kadınlara göre yüksek, kadınların ise; kaçıngan sorun çözme tarzl, dürtüsel-dikkatsiz sorun çözme tarzı ve olumsuz sorun yöneliminin erkeklere göre daha yüksek olduğu bulunmuştur. Çelik (2009)'in araştırmasında cinsiyet faktörü ile problem çözme arasında istatiksel fark bulunmamıștır.

Çalışmamızın sonuçlarına göre evli doktorların problem çözme becerileri bekarlara göre zayıftır (Tablo 3). Kelleci ve Gölbaşı (2004)'nın çalışmasında medeni durum ile problem çözme arasında bir ilişki olmamakla birlikte evli olanların kişisel kontrol algıları daha yüksektir ve çalışmamızı destekler niteliktedir. $\mathrm{Bu}$ benzerlik evlenme ile kadına düșen sorumluluğun artması ve kontrollü davranma zorunluğu getirmesi ile açllanabilir. Erzincanlı (2010)'nın çalışmasında medeni durumun problem çözme becerilerini etkilemediği belirlenmiştir ve bizim bulgularımız ile örtüşmemektedir.

Çocuk sahibi olmayan doktorların ve hemşirelerin problem çözmede kendilerine güvenleri, problem çözümünde kişisel kontrolleri ve yaklaşma-kaçınma davranış sergilemeleri bekar olanlara klyasla yüksek bulunmuştur (Tablo 3). Bu durum çocuk sahibi olmanın alınan sorumluluk düzeyini artırması ile açiklanabilir.

Önlisans mezunu olan hemşirelerin problem çözmede kendilerine güvenleri $(2,88 \pm 0,5)$ ve lisans mezunu olanların da kişisel kontrolleri $(4,20 \pm 0,95)$ diğer eğitim düzeylerine göre yüksek bulunmuştur (Tablo 4). Erkuş (2015)'un çalışmasında SML mezunu hemşirelerin lisans mezunu hemşirelere göre problem çözme ölçek puanları düşük, bulunmuş ve bizim çalışma sonuçlarımızı destekler niteliktedir. Erdem (1995), Kelleci ve Gölbaşı (2004), Çelik ve Yurdakul (2009)'un çalışmalarında eğitim düzeyleri ile problem çözme becerileri arasında bir ilişki olmaması, hemşirelerin daha çok bağımlı fonksiyonlarını kullanmaları ve beklenen bakımın rol ve sorumlulukların eğitim düzeyine göre farklılık göstermemesi ile açılanmıştır (Kelleci ve Gölbaşı 2004).

Meslekte çalışma süresi bir yıldan az olan hemşirelerin $(2,62 \pm 0,73)$ ve doktorların problem çözmede kendilerine daha güvenli $(2,50 \pm 0,86)$ oldukları bulunmuştur (Tablo 4). Erzincanlı (2010)'nın çalışmasında meslekte çalışma yılı ile "yaklaşma-kaçınma" boyutu arasında ilişki olduğu saptanmıştır ve çalışmamız ile paralellik göstermektedir. Kelleci ve Gölbaşı (2004)'nın çalışmalarında, beş yıldan daha az çalışan hemşirelerin problem çözmede kendilerine güvendikleri saptanmıştır. Literatürde mesleki deneyim ve statü arttıkça problem çözme başarı düzeyi ile kendilerine olan güvenlerinin de arttığını belirtilmektedir. 
(Kelleci ve Gölbaşı, 2004; Erzincanll, 2010). Kişilerin meslekteki çalışma yılı arttıkça aynı problemle karşılaşma durumları artmakta ve geçmiş çözüm deneyimlerini göz önünde bulundurarak farklı problem çözme teknikleri ile problemleri daha kolay çözdüklerini düşündürmektedir.

Tablo 4. Pediatri Hemşire ve Hekimlerinin Mesleki Özelliklerine Göre Problem Çözme Puan Ortalamaları

\begin{tabular}{|c|c|c|c|c|c|}
\hline & & PCYG $\bar{x} \pm s s$ & YK $\overline{\mathbf{X}} \pm \mathbf{S S}$ & KK $\overline{\mathbf{X}} \pm \mathbf{s S}$ & PÇTÖP $\bar{x} \pm s s$ \\
\hline \multicolumn{6}{|c|}{ Pediatri servisinde çalışma süresi } \\
\hline & 1 Yll ve Altı & $2,22 \pm 0,75$ & $2,45 \pm 0,79$ & $3,76 \pm 1,36$ & $2,61 \pm 0,54$ \\
\hline & $2-5$ Yll & $2,42 \pm 0,72$ & $2,53 \pm 0,70$ & $3,59 \pm 1,20$ & $2,70 \pm 0,47$ \\
\hline \multirow[t]{6}{*}{ Hemşire $^{* *}$} & 6-10 Yll & $2,49 \pm 0,76$ & $2,63 \pm 0,59$ & $4,40 \pm 0,93$ & $2,84 \pm 0,44$ \\
\hline & $11-20$ Yll & $2,29 \pm 0,45$ & $2,67 \pm 0,45$ & $4,05 \pm 1.00$ & $2,78 \pm 0,31$ \\
\hline & 20 Yıl Üstü & $2,07 \pm 0,48$ & $2,49 \pm 0,41$ & $4,11 \pm 1,45$ & $2,56 \pm 0,26$ \\
\hline & & $\mathrm{p}=0,208$ & $\mathrm{p}=0.460$ & $p=0,034$ & $\mathrm{p}=0,712$ \\
\hline & 1 Yll ve Altı & $2,34 \pm 0,71$ & $2,47 \pm 0,61$ & $4,27 \pm 1,27$ & $2,71 \pm 0,41$ \\
\hline & $2-5$ Yll & $1,98 \pm 0,74$ & $2,12 \pm 0,70$ & $4,13 \pm 1,11$ & $2,41 \pm 0,50$ \\
\hline \multirow[t]{4}{*}{ Doktor** } & 6-10 Yll & $1,86 \pm 0,68$ & $2,02 \pm 0,81$ & $4,20 \pm 1,56$ & $2,33 \pm 0,37$ \\
\hline & $11-20$ Yll & $1,88 \pm 0,61$ & $2,06 \pm 0,62$ & $4,73 \pm 0,50$ & $2,50 \pm 0,39$ \\
\hline & 20 Yll Üstü & $1,27 \pm$ & $1,44 \pm$ & $6.00 \pm$ & $2.00 \pm$. \\
\hline & & $\mathrm{p}=0,053$ & $p=0,009$ & $p=0,037$ & 0,130 \\
\hline \multicolumn{6}{|c|}{ Meslekte çalışma süresi } \\
\hline & $1-5$ Yll & $2,62 \pm 0,73$ & $2,72 \pm 0,61$ & $3,63 \pm 1,35$ & $2,84 \pm 0,45$ \\
\hline & 6-10 Yll & $2,19 \pm 0,57$ & $2,42 \pm 0,66$ & $4,07 \pm 1,12$ & $2,63 \pm 0,41$ \\
\hline \multirow[t]{6}{*}{ Hemşire** } & 11-15 Yll & $2,30 \pm 0,78$ & $2,54 \pm 0,72$ & $3,83 \pm 1,11$ & $2,69 \pm 0,50$ \\
\hline & $16-20$ Yll & $2,19 \pm 0,49$ & $2,47 \pm 0,46$ & $4,40 \pm 1,15$ & $2,72 \pm 0,39$ \\
\hline & 20 Yıl Üstü & $2,33 \pm 0,66$ & $2,61 \pm 0,51$ & $4,2 \pm 1,13$ & $2,72 \pm 0,38$ \\
\hline & & $\mathrm{p}=0,308$ & $p=0,643$ & $p=0,294$ & 0,696 \\
\hline & 1-5 Yll & $2,50 \pm 0,86$ & $2,58 \pm 0,77$ & $3,92 \pm 1,21$ & $2,74 \pm 0,56$ \\
\hline & 6-10 Yll & $1,71 \pm 0,39$ & $2,04 \pm 0,5$ & $4,13 \pm 1,46$ & $2,29 \pm 0,28$ \\
\hline \multirow[t]{4}{*}{ Doktor** } & 11-15 Yll & $1,97 \pm 0,58$ & $2,05 \pm 0,65$ & $4,33 \pm 0,99$ & $2,42 \pm 0,41$ \\
\hline & $16-20$ Yll & $1,41 \pm 0,35$ & $1,59 \pm 0,21$ & $4,80 \pm 0,75$ & $2,10 \pm 0,13$ \\
\hline & 20 Yll Üstü & $1,70 \pm 0,52$ & $1,71 \pm 0,25$ & $5,33 \pm 0,99$ & $2,28 \pm 0,24$ \\
\hline & & $\mathrm{p}=0,007$ & $p=0,023$ & 0,393 & 0,034 \\
\hline \multicolumn{6}{|c|}{ Çalıştığı kurum } \\
\hline & Devlet & $2,32 \pm 0,69$ & $2,58 \pm 0,64$ & $3,6 \pm 1,34$ & $2,68 \pm 0,44$ \\
\hline \multirow[t]{4}{*}{ Hemşire* } & Özel & $2,44 \pm 0,67$ & $2,76 \pm 0,97$ & $3,4 \pm 1,26$ & $2,8 \pm 0,6$ \\
\hline & Üniversite & $2,36 \pm 0,68$ & $2,49 \pm 0,53$ & $4,49 \pm 0,67$ & $2,75 \pm 0,41$ \\
\hline & & $\mathrm{p}=0,853$ & $\mathrm{p}=0,588$ & $p=0,006$ & $\mathrm{p}=0,924$ \\
\hline & Devlet & $1,95 \pm 0,51$ & $2,11 \pm 0,62$ & $4,35 \pm 0,8$ & $2,43 \pm 0,39$ \\
\hline \multirow[t]{3}{*}{ Doktor } & Özel & $3,14 \pm 0,19$ & $2,63 \pm 0,09$ & $3,5 \pm 1,84$ & $3 \pm 0,28$ \\
\hline & Üniversite & $2,01 \pm 0,82$ & $2,18 \pm 0,76$ & $4,21 \pm 1,39$ & $2,45 \pm 0,52$ \\
\hline & & $\mathrm{p}=0,085$ & $\mathrm{p}=\mathbf{0 , 0 2 0}$ & $\mathrm{p}=0,133$ & $p=0,028$ \\
\hline
\end{tabular}

* Mann Whitney U testi, ${ }^{* *}$ Kruskal Wallis H testi.

\section{Hekim ve hemşirelerin kişisel ve mesleki bulguları ile tükenmişlik tartışılması}

Sağlık çalışanlarında tükenmişlik yaşama durumunu belirlemek için yapılan çalışmalarda; yaş, eğitim, medeni ve çocuk sahibi olma durumu, çalıșma koşulları, öfke kontrolü ve problem çözme becerisi gibi birçok faktörün etkilediği belirtilmektedir (Ağapınar, 2011). Sağlık çalışanlarına yönelik yapılan araştırmalarda duygusal tükenme ve duyarsızlaşma puanlarının diğer mesleklere göre yüksek olduğu saptanmıştır (Kaçmaz, 2005).
Çalışmamızda pediatri doktor ve hemşirelerinin duygusal tükenme yaşadıkları ve kişisel başarılarının yüksek, duyarsızlaşma algısının düşük olduğu belirlenmiştir (Tablo 1).

Öztürk ark. (2014)'nın araştırmasında duygusal tükenmişlik ve duyarsızlaşmanın orta düzeyde, kişisel başarı ve tükenmişliğin yüksek düzeyde olduğu saptanmıştır. Kocaman (2017)'nin çalışmasında Maslach Tükenmişlik Ölçeği toplam puan ortalaması orta düzeyde bulunmuştur. Alan ve ark. (2018)'nın çalıșmasında duygusal tükenme orta, duyarsızlaşma düşük, 
kişisel başarı puanı ise yüksek bulunmuş ve çalışmamız ile paralellik göstermektedir.

Çalışmamızda 26-35 yaş aralığında olan doktorların ve 25 yaşından küçük hemşirelerin daha fazla tükenme yaşadıkları belirlenmiștir
(Tablo 5). Erci ve ark (2000), Ergin ve ark. (2009), Ağapınar (2011) ve Kocaman (2017)'ın çalışmalarında yaşın tükenmişliği etkilemediği belirlenmiştir.

Tablo 5. Pediatri Hemşire ve Hekimlerinin Kişisel Özelliklerine Göre Tükenmişlik Puan Ortalamaları

\begin{tabular}{|c|c|c|c|c|c|}
\hline Yaşı & & DT & D & KB & TT puan \\
\hline \multirow{5}{*}{ Hemşire** } & 25 ve Altı & $31,38 \pm 14,32$ & $12,06 \pm 7,7$ & $27,06 \pm 12,23$ & $70,5 \pm 21,46$ \\
\hline & $26-35$ & $27,54 \pm 12,07$ & $8,81 \pm 6,31$ & $33,32 \pm 10,06$ & $69,68 \pm 19,42$ \\
\hline & $36-45$ & $22,53 \pm 8,96$ & $7,9 \pm 5,93$ & $34,97 \pm 9,74$ & $65,4 \pm 15,12$ \\
\hline & $46-55$ & $30,89 \pm 12,18$ & $10,11 \pm 7,32$ & $32,33 \pm 11,4$ & $73,33 \pm 15,47$ \\
\hline & & $p=0,086$ & $p=0,343$ & $p=0,142$ & $p=0,393$ \\
\hline \multirow{6}{*}{ Hekim** } & 25 ve Altı & $27.00 \pm 6,56$ & $9,60 \pm 3,78$ & $29,6 \pm 13,24$ & $66,2 \pm 18,05$ \\
\hline & $26-35$ & $33,87 \pm 11,76$ & $13,83 \pm 7,01$ & $32,22 \pm 8,51$ & $79,91 \pm 13,8$ \\
\hline & $36-45$ & $23,5 \pm 11,4$ & $9,44 \pm 6,51$ & $38,81 \pm 6,87$ & $71,75 \pm 14,1$ \\
\hline & $46-55$ & $26,8 \pm 13,85$ & $10,2 \pm 5,59$ & $41,20 \pm 8,44$ & $78,2 \pm 12,4$ \\
\hline & 55 Üstü & $17,5 \pm 3,54$ & $5.00 \pm 0.00$ & $40.00 \pm 8,49$ & $62,5 \pm 4,95$ \\
\hline & & $p=0,048$ & $\mathrm{p}=0,051$ & $\mathrm{p}=0,052$ & $p=0,139$ \\
\hline \multicolumn{6}{|l|}{ Cinsiyeti } \\
\hline \multirow{3}{*}{ Hemşire* } & Kadın & $26,91 \pm 11,89$ & $9,22 \pm 6,55$ & $32,92 \pm 10,75$ & $69,05 \pm 18,14$ \\
\hline & Erkek & $26,83 \pm 13,14$ & $9.00 \pm 7,92$ & $29,17 \pm 9,58$ & $65.00 \pm 17,72$ \\
\hline & & $\mathrm{p}=0,975$ & $\mathrm{p}=0,937$ & $\mathrm{p}=0,261$ & $\mathrm{p}=0,235$ \\
\hline \multirow{3}{*}{ Hekim* } & Kadın & $32,36 \pm 11,02$ & $11,82 \pm 6,2$ & $33,96 \pm 9,50$ & $78,14 \pm 14,45$ \\
\hline & Erkek & $24,04 \pm 11,90$ & $10,74 \pm 7,23$ & $36,74 \pm 8,59$ & $71,52 \pm 14,14$ \\
\hline & & $\mathrm{p}=0,013$ & $\mathrm{p}=0,236$ & $\mathrm{p}=0,329$ & $\mathrm{p}=0,112$ \\
\hline \multicolumn{6}{|c|}{ Medeni durumu } \\
\hline \multirow{3}{*}{ Hemşire** } & Evli & $26,26 \pm 12,21$ & $8,74 \pm 6,82$ & $33,85 \pm 11,26$ & $68,85 \pm 18,64$ \\
\hline & Bekar & $28,23 \pm 11,32$ & $10,17 \pm 6,11$ & $30,23 \pm 9,02$ & $68,63 \pm 17,05$ \\
\hline & & $\mathrm{p}=0,323$ & $\mathrm{p}=0,176$ & $p=0,039$ & $\mathrm{p}=0,838$ \\
\hline \multirow{4}{*}{ Hekim** } & Evli & $26,69 \pm 12,3$ & $10,81 \pm 7,13$ & $38,58 \pm 6,87$ & $76,08 \pm 13,59$ \\
\hline & Bekar & $30,61 \pm 11,82$ & $12,3 \pm 6,24$ & $32,43 \pm 9,56$ & $75,35 \pm 15,86$ \\
\hline & Dul & $30,50 \pm 14,85$ & $7.00 \pm 2,83$ & $23,5 \pm 14,85$ & $61 \pm 2,83$ \\
\hline & & $\mathrm{p}=0,475$ & $\mathrm{p}=0,270$ & $p=0,025$ & $\mathrm{p}=0,244$ \\
\hline \multicolumn{6}{|c|}{ Çocuğu olup olmadığı } \\
\hline \multirow{3}{*}{ Hemşire* } & Var & $24,75 \pm 12,53$ & $8,13 \pm 6,6$ & $33,75 \pm 11,7$ & $66,64 \pm 18,52$ \\
\hline & Yok & $29,82 \pm 10,44$ & $10,67 \pm 6,4$ & $31,21 \pm, 02$ & $71,69 \pm 17,2$ \\
\hline & & $p=0,019$ & $p=0,030$ & $\mathrm{p}=0,083$ & $\mathrm{p}=0,244$ \\
\hline \multirow{3}{*}{ Hekim* } & Var & $24,17 \pm 11,4$ & $9,46 \pm 7,2$ & $38,79 \pm 8,51$ & $72,42 \pm 13,39$ \\
\hline & Yok & $32,56 \pm 11,42$ & $13.00 \pm 5,72$ & $32,04 \pm 8,58$ & $77,59 \pm 15,34$ \\
\hline & & $p=0,009$ & $p=0,006$ & $p=0,004$ & $\mathrm{p}=0,113$ \\
\hline \multicolumn{6}{|l|}{ Eğitim } \\
\hline \multirow{5}{*}{ Hemşire** } & SML & $32,37 \pm 13,68$ & $12,68 \pm 7,80$ & $28,84 \pm 12,05$ & $73,89 \pm 19,24$ \\
\hline & Ön lisans & $38.00 \pm 18,19$ & $17.00 \pm 9,64$ & $27,67 \pm 12,66$ & $73,89 \pm 19,24$ \\
\hline & Lisans & $26.00 \pm 10,5$ & $8,24 \pm 5,45$ & $34,44 \pm 8,40$ & $68,69 \pm 5,50$ \\
\hline & YL & $21,38 \pm 10,13$ & $6,88 \pm 6,09$ & $32,19 \pm 14,5$ & $60,44 \pm 22,09$ \\
\hline & & $p=0,049$ & $p=0,019$ & $p=0,349$ & $p=0,121$ \\
\hline
\end{tabular}

* Mann Whitney U testi, ${ }^{* *}$ Kruskal Wallis H testi.

Çalışmamızda kadın doktorların tükenmişlikleri erkek doktorlardan ve kadın hemşirelerin tükenmişlikleri erkek hemşirelerden yüksek bulunmuştur.

Ağapınar (2011) ve Koç (2019)'un çalışmasında; medeni durumun duygusal tükenme ve duyarsızlaşmayı etkilediği, bekarlarda duygusal tükenme ve duyarsızlaşmanın anlamlı düzeyde yüksek olduğu, Öztürk ve arkadaşlarının (2014) çalışmasında bekar hemşirelerin duyarsızlaşmalarının daha yüksek olduğu bulunmuş, bunun yanında Kocaman (2017) cinsiyet ve medeni durum ile tükenmişlik arasında anlamlı bir fark bulamamıştır. Evli hemşirelerin ve doktorların kişisel başarılarının yüksek olması aldıkları sosyal destek ile açlklanabilir (Günüşen, 2009; Öztürk ve ark., 2014).

Çalışmamızda pediatri servisinde çalışma süresi ile tükenmişlik arasında anlamlı bir ilişki bulunmamakla birlikte 2-5 yıldır çalışan hemşirelerin ve doktorların duygusal tükenmeleri, duyarsızlaşmaları diğer yıllara kıyasla daha yüksektir (Tablo 6). Meslekte çalışma yılı ile 
tükenmişlik arasında anlamlı istatiksel sonuçlara ulaşılmıştır. Meslekte çalışma süresi 1-5 yıl olan doktorların duygusal tükenme yaşadıkları ve duyarsızlaştıkları belirlenmiştir (Tablo 6). Meslekte çalışma süresi $16-20$ yll olan hemşirelerin ve doktorların ise kişisel başarıları daha yüksektir. Kişisel başarılarının yüksek olması yaşanan deneyimlerin artması ve olaylara bakış açlarının olumlu değişmesi ile açıllanabilir.

Tablo 6. Pediatri Hemşire ve Hekimlerinin Mesleki ve Kişisel Özelliklerine Göre Tükenmişlik Puan Ortalamaları

\begin{tabular}{|c|c|c|c|c|c|}
\hline \multicolumn{2}{|l|}{ Değişkenler } & DT & D & KB & TT puan \\
\hline \multicolumn{6}{|c|}{ Meslekte çalışma süresi } \\
\hline \multirow{6}{*}{ Hemşire** } & 1-5 Yll & $32,55 \pm 14,02$ & $11,5 \pm 6,81$ & $29,55 \pm 11,73$ & $73,59 \pm 21,25$ \\
\hline & 6-10 Yıl & $24,48 \pm 9,24$ & $7,87 \pm 6,76$ & $34,65 \pm 9,41$ & $67 \pm 15,75$ \\
\hline & 11-15 Yll & $26,5 \pm 11,67$ & $10,33 \pm 6,51$ & $30,71 \pm 10,56$ & $67,54 \pm 18,87$ \\
\hline & $16-20$ Yll & $27,13 \pm 12,29$ & $9,25 \pm 6,23$ & $37,88 \pm 6,22$ & $74,25 \pm 14,2$ \\
\hline & 20 Yıl Üstü & $22,87 \pm 10,72$ & $6,07 \pm 5,36$ & $34,6 \pm 11,99$ & $63,53 \pm 16,52$ \\
\hline & & $\mathrm{p}=0,182$ & $\mathrm{p}=0,051$ & $\mathrm{p}=0,189$ & $\mathrm{p}=0,453$ \\
\hline \multirow{6}{*}{ Hekim** } & 1-5 Yll & $36,18 \pm 9,23$ & $14,47 \pm 6,47$ & $30,53 \pm 9,81$ & $81,18 \pm 16,03$ \\
\hline & 6-10 Yll & $27,45 \pm 13$ & $10,45 \pm 6,99$ & $37,18 \pm 8,13$ & $75,09 \pm 12,8$ \\
\hline & 11-15 Yll & $22,88 \pm 11,17$ & $9,63 \pm 6,37$ & $37,25 \pm 8,39$ & $69,75 \pm 14,27$ \\
\hline & $16-20$ Yll & $23,75 \pm 7,68$ & $9,5 \pm 5,92$ & $41,25 \pm 5,44$ & $74,5 \pm 7,94$ \\
\hline & 20 Yıl Üstü & $27 \pm 16,64$ & $8,33 \pm 5,77$ & $35,67 \pm, 61$ & $71 \pm 15,13$ \\
\hline & & $p=0,020$ & $\mathrm{p}=0,076$ & $\mathrm{p}=0,134$ & $\mathrm{p}=0,131$ \\
\hline \multicolumn{6}{|c|}{ Çalıştığı kurum } \\
\hline & Devlet & $27,98 \pm 12,24$ & $10,32 \pm 6,64$ & $31,64 \pm 11,88$ & $69,94 \pm 20,23$ \\
\hline \multirow{2}{*}{ Hemşire** } & Özel & $33,29 \pm 13,1$ & $12,29 \pm 7,06$ & $30,43 \pm 12,58$ & $76 \pm 9,13$ \\
\hline & Üniversite & $\begin{array}{l}24,39 \pm 10,89 \\
p=0,113\end{array}$ & $\begin{array}{l}7,26 \pm 6,08 \\
\mathbf{p}=\mathbf{0 , 0 2 0}\end{array}$ & $\begin{array}{l}34,37 \pm 8,58 \\
p=0,673\end{array}$ & $\begin{array}{l}66,03 \pm 16,11 \\
p=0,053\end{array}$ \\
\hline \multirow{4}{*}{ Hekim** } & Devlet & $25,71 \pm 9,09$ & $10,14 \pm 5,42$ & $36,9 \pm 9,27$ & $72,76 \pm 13,08$ \\
\hline & Özel & $44,5 \pm 4,95$ & $19,5 \pm 3,54$ & $29,5 \pm 3,54$ & $93,5 \pm 12,02$ \\
\hline & Üniversite & $29,64 \pm 13,44$ & $11,64 \pm 7,29$ & $34,36 \pm 9,19$ & $75,64 \pm 15,18$ \\
\hline & & $\mathrm{p}=0,128$ & $\mathrm{p}=0,242$ & $\mathrm{p}=0,289$ & $\mathrm{p}=0,179$ \\
\hline \multicolumn{6}{|c|}{ Meslek seçimi } \\
\hline \multirow{4}{*}{ Hemşire ${ }^{* *}$} & Kendim & $25,16 \pm 11,7$ & $8,2 \pm 6,09$ & $34,1 \pm 10,77$ & $67,47 \pm 19,64$ \\
\hline & Aile & $30,52 \pm 10,97$ & $11,89 \pm 6,43$ & $32,74 \pm 9,9$ & $75,15 \pm 15,3$ \\
\hline & Tesadüfen & $26,13 \pm 13,35$ & $7,75 \pm 7,44$ & $28,19 \pm 11,02$ & $62,06 \pm 14,45$ \\
\hline & & $\mathrm{p}=0,103$ & $p=0,007$ & $\mathrm{p}=0,145$ & $p=0,016$ \\
\hline \multirow{3}{*}{ Hekim** } & Kendim & $26,82 \pm 11,29$ & $10,57 \pm 6,41$ & $35,52 \pm 9,48$ & $72,91 \pm 13,42$ \\
\hline & Aile & $39,86 \pm 11,31$ & $16,14 \pm 6,39$ & $33,29 \pm 6,63$ & $89,29 \pm 14,27$ \\
\hline & & $p=0,009$ & $\mathrm{p}=0,056$ & $\mathrm{p}=0,366$ & $p=0,007$ \\
\hline \multicolumn{6}{|l|}{ Yaş } \\
\hline \multirow{5}{*}{ Hemşire** } & 25 ve Altı & $31,38 \pm 14,32$ & $12,06 \pm 7,7$ & $27,06 \pm 12,23$ & $70,5 \pm 21,46$ \\
\hline & $26-35$ & $27,54 \pm 12,07$ & $8,81 \pm 6,31$ & $33,32 \pm 10,06$ & $69,68 \pm 19,42$ \\
\hline & $36-45$ & $22,53 \pm 8,96$ & $7,9 \pm 5,93$ & $34,97 \pm 9,74$ & $65,4 \pm 15,12$ \\
\hline & $46-55$ & $30,89 \pm 12,18$ & $10,11 \pm 7,32$ & $32,33 \pm 11,4$ & $73,33 \pm 15,47$ \\
\hline & Analiz & $\mathrm{p}=0,086$ & $p=0,343$ & $\mathrm{p}=0,142$ & $\mathrm{p}=0,393$ \\
\hline \multirow{6}{*}{ Hekim** } & 25 ve Altı & $27.00 \pm 6,56$ & $9,60 \pm 3,78$ & $29,6 \pm 13,24$ & $66,2 \pm 18,05$ \\
\hline & $26-35$ & $33,87 \pm 11,76$ & $13,83 \pm 7,01$ & $32,22 \pm 8,51$ & $79,91 \pm 13,8$ \\
\hline & $36-45$ & $23,5 \pm 11,4$ & $9,44 \pm 6,51$ & $38,81 \pm 6,87$ & $71,75 \pm 14,1$ \\
\hline & $46-55$ & $26,8 \pm 13,85$ & $10,2 \pm 5,59$ & $41,20 \pm 8,44$ & $78,2 \pm 12,4$ \\
\hline & 55 Üstü & $17,5 \pm 3,54$ & $5.00 \pm 0.00$ & $40.00 \pm 8,49$ & $62,5 \pm 4,95$ \\
\hline & Analiz & $p=0,048$ & $\mathrm{p}=0,051$ & $\mathrm{p}=0,052$ & $\mathrm{p}=0,139$ \\
\hline \multicolumn{6}{|l|}{ Cinsiyet } \\
\hline \multirow{3}{*}{ Hemşire* } & Kadın & $26,91 \pm 11,89$ & $9,22 \pm 6,55$ & $32,92 \pm 10,75$ & $69,05 \pm 18,14$ \\
\hline & Erkek & $26,83 \pm 13,14$ & $9.00 \pm 7,92$ & $29,17 \pm 9,58$ & $65.00 \pm 17,72$ \\
\hline & Analiz & $\mathrm{p}=0,975$ & $\mathrm{p}=0,937$ & $\mathrm{p}=0,261$ & $\mathrm{p}=0,235$ \\
\hline \multirow{3}{*}{ Hekim* } & Kadın & $32,36 \pm 11,02$ & $11,82 \pm 6,2$ & $33,96 \pm 9,50$ & $78,14 \pm 14,45$ \\
\hline & Erkek & $24,04 \pm 11,90$ & $10,74 \pm 7,23$ & $36,74 \pm 8,59$ & $71,52 \pm 14,14$ \\
\hline & Analiz & $\mathrm{p}=0,013$ & $\mathrm{p}=0,236$ & $\mathrm{p}=0,329$ & $\mathrm{p}=0,112$ \\
\hline
\end{tabular}

* Mann Whitney U testi, ** Kruskal Wallis H testi.

$\mathrm{Bu}$ araștırmanın örneklem grubunu olușturan pediatri hemşirelerinin öfke kontrol düzeylerinin yüksek $(20,86 \pm 6,70)$, problem çözme becerilerinin zayıf (hemşire $=2,34 \pm 0,68$ ) olduğu, pediatri doktorlarının öfke kontrolünün zayıf
$(21,63 \pm 6,52)$, problem çözme becerilerinin yüksek $(2,46 \pm 0,47)$ olduğu ve her iki meslek grubunun da tükenmişlik yaşadıkları (doktor= $28,61 \pm 12,06$, hemşire $=26,90 \pm 11,90$ ) belirlenmiștir. Belirlenen sonuçlar doğrultusunda; hem- 
şirelik eğitiminde ve mezuniyet sonrasında kurumlarda öfke ve problem çözme yeterliliğine yönelik programların geliştirilmesi önerilmektedir.

Çıkar çatışması bildirimi: Yazarlar herhangi bir kişi ya da kuruluş ile çıkar çatışması beyan etmemektedir.

Teşekkür: Yazarlar bu çalışmaya katılan hekim ve hemşirelere teşekkür eder.

\section{KAYNAKLAR}

Abaan S, Altıntoprak A (2005) Hemşirelerde problem çözme becerileri: öz değerlendirme sonuçlarının analizi. Hacettepe Üniversitesi Hemşirelik Yüksekokulu Dergisi. 12(1): 62-76.

Ağapınar S, Güler H (2014) Ağrı ilinde çalışan ebelerin tükenmişlik düzeylerinin iş doyumları ve empatik eğilimleri üzerine etkisi. TAF Preventive Medicine Bulletin. 13(2) 141-150.

Duran S, Karadaş A, Kadder E (2016) Hemşirelik öğrencilerinin tolerans düzeyleri ile öfke kontrolleri arasındaki ilişkinin incelenmesi. Sdü Sağlık Bilimleri Enstitüsü Dergisi. 7 (3): 39-44.

Alan H, Arslan E, Altınışık B (2018) Hemodiyaliz hemşirelerinin tükenmişlik düzeyi ile empati becerileri arasındaki ilișki. türk nefroloji, Diyaliz ve Transplantasyon Hemşireleri Derneği Nefroloji Hemşireliği Dergisi. 2(13): 37-44.

Bahar M (2006) Yataklı tedavi kurumlarında çalışan yönetici hemşirelerin problem çözme becerileri ve yaratıcılık düzeyleri. Marmara Üniversitesi Sağlık Bilimleri Enstitüsü, İstanbul.

Balkaya F, Şahin N (2003) Çok boyutlu öfke ölçeği. Türk Psikiyatri Dergisi. 14(3):192-202.

Baran M, Okanlı A (2015) Hemşirelerde öfke düzeyinin iş doyumuna etkisi. Anadolu Hemşirelik ve Sağlık Bilimleri Dergisi. 18(1): 42-49.

Batıgün D A, Oktay B (2014) Aleksitimi: Bağlanma, benlik algısı, kişilerarası iliş̧i tarzları ve öfke. Türk Psikoloji Yazıları. 17 (33): 31-40.

Bayrı F, Kelleci M (2009) Hemşirelerin sürekli öfke ve öfke ifade tarzları ile genel sağlık durumları arasındaki ilişki. Turkiye Klinikleri J Nurs Sci. (2) 6570.

Cebeci R (2018) Hemşirelerin öfke eğilimini etkileyen kişisel, çevresel ve mesleki faktörlerin değerlendirilmesi. Marmara Üniversitesi Sağlık Bilimleri Enstitüsü, İstanbul

Conk Z, Başbakkal Z, Bal Yılmaz H, Bolışık B (2018) Pediatri hemşireliği. Akademisyen Yayınları.

Çavuşoğlu H (2001) Çocuk sağlığı hemşireliği. Cilt 1, Genişletilmiş 6. Baskı. Ankara, Bizim Büro Basımevi.

Çelik C, Yurdakul M (2009) Hastane yöneticilerinin problem çözme becerileri: Bir alan araştırması. Çukurova Üniversitesi. Sosyal Bilimler Enstitüsü Dergisi. 18(1): 95-108.

D'zurilla T J, Nezu A M, Maydeu-Olivares A (2004) Social problem solving: Theory and assessment. (Ed. Thomas J D'zurilla; Edward C Chang; Lawrence J Sanna). Social Problem Solving: Theory, Research, And Training, Ss. 11-27, Washington, Dc: American Psychological Association.

Dinç K (2008) Yardım mesleklerinde tükenmişlik sendromu. Ankara Üniversitesi Sosyal Bilimler Enstitüsü, Ankara.

Doğan S, Güler H, Kelleci M (2001) Hastaların öfkeli davranıșları karșısında hemșirelerin yaklașımları. Cumhuriyet Üniversitesi Hemşirelik Yüksekokulu Dergisi. 5 (1):26-32.

Durmuş A B, Öztürk H, Kurşun M (2000) Hemşirelerin öfke düzeyleri ve öfke ifade tarzlarının belirlenmesi. Ege Üniversitesi Hemşirelik Yüksek Okulu Dergisi. 16 (2-3): 21-29.

Engin E (2004) Psikiyatri kliniğinde çalışan hemşirelerin öfke düzeyleri ile iş motivasyonları arasındaki ilişkinin incelenmesi. Eğe Üniversitesi Sağlık Bilimleri Enstitüsü, İzmir

Erci B, Aydın G, Tortumluoğlu, G (2000) Koruyucu sağllk hizmetlerinde görev yapan hemşire ve ebelerin sağlıklı yaşam biçimi davranışları ve tükenmişlik düzeyleri, Atatürk Üniversitesi Hemşirelik Yüksekokulu Dergisi. 3(1):10-15.

Erdem Y (1995) Yüksekokul ve sağlık meslek lisesi mezunu hemşirelerin problem çözme becerilerini algılama durumları. 4. Ulusal Hemşirelik Kongresi. Ankara.

Ergin, D, Celasin N, Akın Ş, Altan ö, Bakırlığlu ö, Bozkurt S, (2009) Dahili kliniklerde görev yapan hemșirelerin tükenme ve empatik beceri düzeyleri ve bunları etkileyen faktörlerin belirlenmesi, Firat Sağlık Hizmetleri Dergisi. 4(11):49-64.

Erkek N, Özgür G, Babacan G A (2006) Hipertansiyon tanısı alan hastaların sürekli öfke ve öfke ifade tarzları. Cumhuriyet Üniversitesi Hemşirelik Yüksekokulu Dergisi. 10(2): 9-18. 
Erkuş B, Bahçecik N (2015) Özel hastanelerde çalışan yönetici hemşirelerin ve hemşirelerin eleştirel düşünme düzeyi ve problem çözme becerileri. Marmara Üniversitesi Sağlık Bilimleri Enstitüsü Dergisi. 1(1): 1-9.

Ertem İ Ö (2008) Gelişimsel pediatri. Çocuk-Dergisi. 8(4): 212-216.

Erzincanlı S, Zaybak A (2015) Hemşirelerde eleştirel düşünme eğilimi ve problem çözme becerileri arasındaki ilișki. Uluslararası Hakemli Hemşirelik Araştırmaları Dergisi 2(3): 26-38.

Günüşen N, Üstün B, (2010) Türkiye'de ikinci basamak sağlık hizmetlerinde çalışan hemşire ve hekimlerde tükenmișlik: literatür incelemesi. Dokuz Eylül Üniversitesi Hemşirelik Yüksekokulu Dergisi. 3(1): 40-51.

Hoyt P (2007) An international approach to problem solving for better health nursing (PSBHN). International Nursing Review, 54(1): 100-106.

İlhan HK (2014) Hemşirelerin çalışma ortamında öfke düzeyi ve öfke ifade tarzı haliç üniversitesi. Sağlık Bilimleri Enstitüsü, İstanbul.

Kaçmaz N (2005) Tükenmişlik sendromu. İstanbul Tıp Fakültesi Dergisi. 68(1): 29-32.

Karakurt N, Ekinci M (2015) Hemşirelerin algıladıkları sosyal destek ile problem çözme becerisi arasındaki ilişki. Gümüşhane Üniversitesi Sağlık Bilimleri Dergisi. 4(4): 574-93.

Kaya N, Solmaz Ş (2009) Bir üniversite hastanesinin kbb kliniğinde çalışan hemşirelerin öfke ve öfke İfadesi. Türkiye Klinikleri Hemşirelik Bilimleri Dergisi. 1(2): 56-64.

Kelleci M, Gölbaşı Z (2004) Bir üniversite hastanesinde çalışan hemşirelerin problem çözme becerilerinin bazı değişkenler açısından incelenmesi. Cumhuriyet Üniversitesi Hemșirelik Yüksekokulu Dergisi. 8(2): 1-8.

Keskin G, Gümüş BA, Engin E (2011) Bir grup sağlık çalışanında öfke ve mizaç özellikleri: ilişkisel bir inceleme. Düşünen Adam Psikiyatri ve Nörolojik Bilimler Dergisi. 24(3):199-208.

Kırılmaz H, Yorgun S, Atasoy A (2016) Sağlık çalışanlarında psikososyal risk faktörlerini belirlemeye yönelik bir araştırma. International Journal Of Cultural And Social Studies August. 2(1): 66-82.

Koç İ (2019) Sağlık çalışanlarında tükenmişlik sendromunun iş doyumu ve depresyonla ilişkisi.
Sağlık Bilimleri Üniversitesi Haseki Sağlık Uygulama ve Araştırma Merkezi. Tıpta Uzmanlık Tezi.

Lafçı D, Pehlivan S, Demiray G (2016) Cerrahi kliniklerinde çalışan hekim ve hemşirelerin ekip çalışmasına ilişkin görüşleri. Sağlık ve Hemşirelik Yönetim Dergisi. 3(2): 55-64.

Marakoğlu M, Kargın Ç N, Armutlukuyu M (2013) Tıp fakültesi araştırma görevlilerinde tükenmişlik sendromu ve ilişkili faktörlerin değerlendirilmesi. Genel Tıp Dergisi. 23(4): 102-108.

McEwen, M, Brown S C (2002) Conceptual frameworks in undergraduate nursing curricula: report of a national survey. Journal of Nursing Education. 41(1): 5-14.

Öztürk S, Özgen R, Şişman H, Baysal D, Sarıakçalı N, Aslaner E, Kum P, Gürel D, Gezer D, Akıl Y, Yıldızdaş R D (2014) Bir üniversite hastanesi"nde çalışan hemşirelerin tükenmişlik düzeyi ve sosyal desteğin etkisi. Cukurova Medical Journal. 39 (2014): 752-764.

Yıldızdaş DR (2014) Bir üniversite hastanesi'nde çalışan hemșirelerin tükenmișlik düzeyi ve sosyal desteğin etkisi. Çukurova Medical Journal. 39(4):752764.

Polat H (2013) Hemşirelerin problem çözme becerileri ve atılganlıkları arasındaki ilişkinin incelenmesi. Adnan Menderes Üniversitesi Sağlık Bilimler Enstitüsü, Aydın.

Portakal N (2018) Hemşirelerde öfkeyi etkileyen faktörler ve öfke ifade biçimi. Okan Üniversitesi Sağlık Bilimleri Enstitüsü, İstanbul.

Terri K, Carman S (2013) Essentials of pediatric nursing. Wolters Kluwer Health Lippincott Williams \& Wilkins.

Terzioğlu F (2006) The perceived problem solving ability of nurse managers. J Nurs Manag. 14(5): 340347.

Tezel A, Arslan S, Topal M, Aydoğan Ö, Koç Ç, Şenlik M (2009) Hemşirelik öğrencilerinin problem çözme becerileri ve depresyon düzeylerinin incelenmesi. Atatürk Üniversitesi Hemşirelik Yüksekokul Dergisi. 12(4): 1-10.

Thomas S P (2004) Transforming nurses stress and anger, steps toward healing. Second Edition, New York, Springer Publishing Company.

Törüner E K, Büyükgönenç L (2011) çocuk sağlığ temel hemşirelik yaklaşımları, büyüme ve gelişme, Göktuğ Yayıncılık. Amasya. 
Ulupınar S (1999) Hemşirelikte sorun çözme kuramları. VII. Ulusal Hemşirelik Kongresi Bildiri Kitabı. Erzurum.

Yıldırım A, Kutlu L, Çimen S (2002). The relationship between nurses' sociotropy-autonomy personality characteristics and trait anger: Anger Expression Styles. 6(1): 41-52.

Yıldırım S (2005) Psikiyatri servisinde çalışan hemşirelerin sürekli öfke ve öfke ifade düzeylerinin belirlenmesi. osmangazi üniversitesi, Sağllk Bilimleri Enstitüsü, Eskişehir

Yılmaz S (2009) Hemşirelerin öfke ifade etme ve iletişim biçimleri. Haliç Üniversitesi Sağlık Bilimleri Enstitüsü, İstanbul.

Yüksel A (2014) Hemşirelerin öfke düzeyi ve verimliliğe ilişkin tutumlarının incelenmesi, Haliç Üniversitesi Sağlık Bilimleri Enstitüsü, İstanbul

Yüzer S, Alıcı D, Yiğit R (2008) Pediatri hemşirelerinin rolleri ve fonksiyonları ölçeğinin uygulanmasının geliştirilmesi: Güvenirliği ve Geçerliliği. Atatürk Üniversitesi Hemşirelik Yüksekokulu Dergisi. 11(4): 19-28. 